\title{
PENGARUH PENDIDIKAN KESEHATAN TENTANG HIVIAIDS TERHADAP PENINGKATAN PENGETAHUAN REMAJA
}

The Effect Of Health Education On Hiv / Aids On The Improvement Of Knowledge Of Youth

\author{
Samsir ${ }^{1}$, Sulasri $^{2}$, La Masahuddin ${ }^{3}$ \\ 1,2,3Akademi Keperawatan Pelamonia Kesdam VII/Wirabuana \\ E-mail : samsir.syam1990@gmail.com \\ $\mathrm{Hp}: 085240854735$
}

\begin{abstract}
Human Immunodeficiency Virus / Acquired-Immunodeficiency Syndrome (HIV/AIDS) is now a global health epidemic affecting all ages and genders. Based on data from the United Nations Program on HIV / AIDS (UNAIDS), there were 36.9 million people in various countries living with HIV and AIDS in 2017. Of the total sufferers, 1.8 million were children under 15 years of age. . Promiscuity in adolescents can ease the risk of contracting HIV and AIDS. Some teenagers do not have correct knowledge about reproductive health and sexuality. Incorrect information can plunge adolescents into promiscuity which can lead to contracting HIV and AIDS. Based on data from the South Sulawesi Provincial Health Office in 2018, there were 547 HIV people and 49 AIDS people. The purpose of this study was to determine the effect of health education on HIV / AIDS on increasing the knowledge of adolescents in the Military Academy of the Military Region VII / Wirabuana. Method: This type of research is quantitative with a Quasi Experimental design. Sampling in this study using Simple Random Sampling technique. Data collection was done using a questionnaire (Google Form) and for data analysis using the Wilcoxon Sign Rank Test. Result: statistical test obtained at the time of Pre Test Mean 11.36, Standard Deviation 2.646, $p$ value 0.000 and Post Test, Mean value 16.89, Standard Deviation 2.518, $p$ value 0.000. Conclusion: Based on the research conducted, it is concluded that there is an effect of health education on increasing the knowledge of adolescents in the PelamoniaKesdam VII / Wirabuana Nursing Academy.
\end{abstract}

Keywords : HIVIAIDS, Health Education, Knowledge, Youth

\section{ABSTRAK}

Human Immunodeficiency Virus/Acquired-Immunodeficiency Syndrome (HIVIAIDS) kini menjadi sebuah epidemi kesehatan global yang menyerang seluruh rentang usia dan jenis kelamin. Berdasarkan data dari United Nations Programme on HIV/AIDS (UNAIDS), terdapat 36,9 juta masyarakat berbagai negarahidup bersama HIV dan AIDS pada 2017. Dari total penderita yang ada, 1,8 juta di antaranya adalah anak-anak berusia dibawah 15 tahun. Pergaulan bebas pada remaja dapat mempermudah risiko tertular penyakit HIV dan AIDS. Sebagian remaja tidak memiliki pengetahuan yang benar tentang kesehatan reproduksi dan seksualitas. Informasi yang salah dapat menjerumuskan remaja kedalam pergaulan bebas yang dapat mengarah terhadap tertularnya HIV dan AIDS. Berdasarkan data Dinas Kesehatan provinsiSulawesi Selatan tahun 2018, HIV sebanyak 547 orang dan AIDS sebanyak 49 orang. Tujuan penelitian ini yaitu untuk mengetahui pengaruh pendidikan kesehatan tentang HIV/AIDS terhadap peningkatan pengetahuan remaja di Akper Pelamonia Kesdam VII/Wirabuana. Metode : Jenis penelitian ini adalah Kuantitatif dengan desain Quasi Eksperimental. Pengambilan sampel dalam penelitian ini dengan teknik Simple Random Sampling. Pengumpulan data dilakukan dengan menggunakan kuesioner (Google Form) dan untuk analisa data menggunakan Uji WilcoxonSignRankTest. Hasil: uji statisticyang didapatkan pada saat PreTestMean 11,36, Standar Deviasi 2,646,p value 0,000 dan PostTest, nilai Mean16,89, Standar Deviasi 2,518,p value 0,000 . Kesimpulan : Bedasarkan penelitian yang dilakukan, disimpulkan bahwa ada pengaruh pendidikan kesehatan terhadap peningkatan pengetahuan remaja dilingkungan Akademi Keperawatan Pelamonia Kesdam VII/Wirabuana.

Kata kunci : HIVIAIDS, Pendidikan Kesehatan, Pengetahuan, Remaja

\section{PENDAHULUAN}

Human Immunodeficiency Virus/Acquired Immunodeficiency Syndrome (HIV/AIDS) kini menjadi sebuah epidemi kesehatan global yang menyerang seluruh rentang usia dan jenis kelamin. Berdasarkan data dari UNAIDS, terdapat 36,9 juta masyarakat berbagai negarahidup bersama HIV dan AIDS pada 2017. Dari total penderita yang ada, 1,8 juta di antaranya adalah anak-anak berusia di bawah 15 tahun. Selebihnya adalah orang dewasa, sejumlah 35,1 juta penderita. Masih bersumber dari data tersebut, penderita HIV/AIDS lebih banyak diderita oleh kaum wanita, yakni sebanyak 18,2 juta penderita. Sementara laki-laki sebanyak 16,9 juta penderita. Sayangnya, 25 persen di antaranya, sekitar 9,9 juta 
penderita, tidak mengetahui bahwa mereka terserang HIV atau bahkan mengidap AIDS.

Berdasarkan dataWorld Health Organisation (WHO) dan United Nations International Children's Emergency Fund (UNICEF) pada tahun 2013, wilayah Asia Tenggara memiliki jumlah penderita Human Immunodeficiency Virus \& Ac-quired ImmuneDeficiency Syndrome (HIV dan AIDS) sebanyak 940.000 orang, dan wilayah Asia Tenggara mendudukiperingkat ke dua kasus HIV dan AIDS di dunia setelah wilayah Afrika yang memiliki jumlah orang dengan HIV dan AIDS (ODHA) sebanyak 7.580 .000 orang.

Berdasarkan data statistik kasus HIV dan AIDS di Indonesia bulan Januari-Maret tahun2017 menunjukan penderita HIV pada triwulan I dilaporkan sebanyak 10.376 orang. Persentase infeksi HIV tertinggi berada pada kelompok usia 25-49 tahun $(69,6 \%)$ diikuti kelompok usia 20-24 tahun (17,6\%) dan kelompok usia $\geq 50$ tahun $(6,7 \%)$. Sedangkan pada kasus AIDS pada bulan Januari - Maret tahun 2017 menunjukan penderita AIDS pada triwulan I dilaporkan sebanyak 673 orang. Persentase AIDS tertinggi dilaporkan pada usia 30-39 tahun (38,6\%) dikikuti kelompok usia 20-29 tahun (29,3\%) dan umur 40-49 tahun (16,5\%).

Berdasarkan data Dinas Kesehatan Provinsi Sulawesi Selatan tahun 2015 penderita HIV di Sulsel sebanyak 882 orang, AIDS 305 orang, tahun 2016 kasus HIV 1030 orang dan AIDS 578 orang, untuk 2017 HIV sebanyak 1560 orang dan AIDS 599 orang, sedangkan tahun 2018 HIV 547 orang dan AIDS 49 orang. Kepala bidang Pencegahan Penyakit dinas Kesehatan Sul-sel, mengatakan bahwa dari 24 kabupaten-kota di Sul-sel, kota Makassar yang masuk di peringkat pertama menyusul kota Palopo, dan kabupaten Sidrap. Sebagai contoh, salah satunya adalah kota Makassar merupakan salah satu pintu masuknya urban (pendatang) dari berbagai penjuru daerah, baik lokal maupun luar serta adanya pergaulan bebas yang sekarang ini seolah-olah dianggap hal biasa.

Pergaulan bebas pada remaja dapat mempermudah risiko tertular penyakit menularseksual seperti HIV dan AIDS. Sebagian remaja tidak memiliki penge-tahuan yang benar tentang kesehatan reproduksi dan seksualitas. Informasi yang mereka dapat biasanya berasal dari teman atau media elektronik maupun cetak, yang biasanya kurang atau bahkan tidak akurat. Informasi yang salah dapat menjerumuskan remaja kedalam pergaulan bebas yang dapat mengarah terhadap tertularnya HIV dan AIDS.

Berdasarkan masalah yang terpapar di atas, peneliti tertarik untuk melakukan penelitian mengenai "Pengaruh Pendidikan Dini tentang HIV dan AIDS terhadap Peningkatan Pengetahuan Remaja", dengan upaya promotif dan preventif dapat dilakukan sejak dini untuk meningkatkan sikap positif pada penderita HIV dan AIDS khususnya melalui pendidikan dini tentang HIV dan AIDS pada remaja.

Penelitian ini dilaksanakan dengan tujuan untuk menilai tingkat pengetahuan remaja tentang HIVIAIDS serta menganalisis pengaruh pendidikan kesehatan tentang HIVIAIDS terhadap peningkatan pengetahuan remaja.

\section{METODE PENELITIAN}

Penelitian ini dilakukan di Kampus Akademi Keperawatan Pelamonia Kesdam VII/Wirabuana Makassar tahun 2020. Jenis penelitian ini adalah Kuantitatif dengan desain Quasy Eksperimental dengan rancangan pre-posttest. Pre-test dilakukan sebelum diberikan pendidikan kesehatan untuk menilai pengetahuan remaja tentang HIVIAIDS dan post-testdilakukan setelah diberikan pendidikan kesehatan tentang HIVIAIDS untuk menilai pengaruhnya terhadap pengetahuan remaja. Sampel dalam penelitian ini sebanyak 92 responden yang merupakan mahasiswa baru tahun ajaran 2020-2021 Akademi Keperawatan Pelamonia Kesdam VII/Wirabuana. Teknik pengambilan sampel dalam penelitian ini menggunakan teknik Simple Random Sampling yaitu suatu teknik pengambilan sampel atau elemen secara acak, dimana setiap elemen atau anggota populasi memiliki kesempatan yang sama untuk terpilih menjadi sampel. Pengumpulan data dilakukan dengan menggunakan kuesioner (Google Form) untuk menilai pengetahuan remaja tentang HIVIAIDS. Setelah data sudah terkumpul, selanjutnya akan dilakukan analisis data atau pengolahan data dengan menggunakan SPSS uji Wilcoxon Sign Rank Test

HASIL

Tabel.1

Karakteristik Responden Berdasarkan Jenis Kelamin Mahasiswa Akper Pelamonia (Maba) Tahun 2020

\begin{tabular}{ccc}
\hline Jenis Kelamin & $\mathbf{n}$ & $\%$ \\
\hline Laki - Laki & 17 & 18 \\
Perempuan & 75 & 82 \\
\hline Total & $\mathbf{9 2}$ & $\mathbf{1 0 0}$ \\
\hline
\end{tabular}

Berdasarakan tabel 1, jumlah responden yang berjenis kelamin laki-laki sebanyak 17 orang $(18 \%)$ sedangkan yang berjenis kelamin perempuan sebanyak 75 orang (82\%). 
Tabel. 2

Karakteristik Responden Berdasarkanumur Mahasiswa Akper Pelamonia (Maba) Tahun 2020

\begin{tabular}{ccc}
\hline Umur & $\mathbf{n}$ & $\mathbf{\%}$ \\
\hline 17 & 23 & 25 \\
18 & 48 & 52,17 \\
19 & 16 & 17,39 \\
20 & 5 & 5,43 \\
\hline Total & $\mathbf{9 2}$ & $\mathbf{1 0 0}$
\end{tabular}

Berdasarakan tabel 2, jumlah responden yang berusia 17 tahun sebanyak 23 orang $(25 \%)$, jumlah responden yang berusia 18 tahun sebanyak 48 orang $(52,17 \%)$, jumlah responden yang berusia 19 tahun sebanyak 16 orang $(17,39 \%)$ dan jumlah responden yang berusia 20 tahun sebanyak 5 orang $(5,43 \%)$.

Tabel. 3

Pengaruh Pendidikan Kesehatan HIVIAIDSTerhadapPeningkatan Pengetahuan Remaja di Akademi Keperawatan Pelamonia Kesdam VII/Wirabuana tahun 2020

\begin{tabular}{clc}
\hline Variabel & Mean/Std Dev & $\boldsymbol{P}$ Value \\
\hline Nilai PreTest & $11,36(2,646)$ & \multirow{2}{*}{0,000} \\
\cline { 1 - 2 } Nilai PostTest & $16,89(2,158)$ & \\
\hline
\end{tabular}

Berdasarkan tabel 3 diatas, data menunjukkan nilai pada saat pretest pengetahuan yaitu mean 11,36 dengan Standar Deviasi 2,646 dan penilaian post tes pengetahuan remaja setelah diberikan pendidikan kesehatan yaitu Mean 16,89 dengan Standar Deviasi 2,518. Selanjutnya pada uji statistik menggunakan Uji WilcoxonSignRankTest dengan nilai $P=0,000$. Hal ini menunjukkan bahwa terdapat pengaruh yang bermakna Pendidikan Kesehatan terhadap peningkatan pengetahuan remaja di lingkungan Akademi Keperawatan Pelamonia Kesdam VII/ Wirabuana.

\section{PEMBAHASAN}

Berdasarkan hasil penelitian yang dilakukan tentang pengetahuan HIV/AIDS, distribusi responden paling banyak berdasarkan jenis kelamin yaitu perempuan dengan jumlah 75 orang ( $82 \%)$. Distribusi responden berdasarkan usia didominasi oleh responden dengan usia 18 tahun sebanyak 48 orang $(52,17 \%)$.

Hasil penelitian sebelum dilakukan pendidikan kesehatan pada remaja dalam hal ini mahasiswa baru Akademi Keperawatan Pelamonia Kesdam VII/Wirabuana menunjukkan nilai rata-rata yaitu 11,36 dengan nilai minimal 8 dan nilai maksimal
22.Pengetahuanataukognitif merupakan domain yang sangat penting untuk terbentuknya tindakan seseorang. Pengetahuan seseorang tentang suatu objek mengandung dua aspek yaitu aspek positif dan aspek negatif. (Notoatmodjo, 2012).

Berdasarkan hasil penelitian tersebut dapat diketahui bahwa nilai rata- rata responden sebelum diberikan pendidikan kesehatan berada pada kategori kurang yaitu $11,36 \%$, walaupun ada salah seorang yang pengetahuan nya sudah baik, hal ini ditunjukan dengan nilai maksimum atau tertinggi responden sebesar 22. Hal ini dikarenakan ada beberapa faktor yang mempengaruhi pengetahuan antara lain pendidikan, media massa / informasi, sosial budaya dan ekonomi, Lingkungan, Pengalaman, dan usia (Notoatmodjo, 2012).

Hasil penelitian pengetahuan setelah diberikan pendidikan kesehatan HIVIAIDSmengalamipeningkatan yaitu dari nilai rata rata responden 11, 36 dengan nilai minimal 8 dan maksimal 22 menjadi nilai rata-ratanya 16,89 dengan nilai minimum 11 dan maksimum 22. Data tersebut menunjukkan adanya peningkatan pengetahuan remaja tentang HIVIAIDS. Seperti yang dikemukakan Tribowo dan Pusphandani (2015) bahwa pendidikan kesehatan merupakan semua kegiatan untuk memberikan dan atau meningkatkan pengetahuan, sikap, dan praktik masyarakat dalam memelihara dan meningkatkan kesehatan mereka sendiri. Hal ini sejalan dengan penelitian yang dilakukan oleh Xiaohui Gao, et. al, mengungkapkan bahwa setelah intervensi, semua siswa memiliki perbaikan yang signifikan dalam pengetahuan dan sikap tentang HIVIAIDS $(p=0,05)$, hal ini menunjukkan bahwa intervensi pendidikan meningkatkan pengetahuan siswa secara signifikan dan mengubah sikap positif. Melalui pendidikan kesehatan maka akan memberikan kemudahan untuk memahami materi tentang HIVIAIDS yang dapat berpengaruh terhadap sikap pencegahan responden. Sesuai dengan teori Triwibowo dan Pusphandi (2015) bahwa dalam proses pendidikan kesehatan terdapat tahap motivasi yang berarti diharapkan individu/masyarakat memiliki motivasi untuk melaksanakanperilaku dan sikap yang dianjurkan pada kegiatan tersebut yang mengarah pada sikap pencegahan HIVIAIDS. Siswa yang memiliki pengetahuan yang baik tentang HIVIAIDS maka selanjutnya akan dapat terbentuk sikap yang lebih baik. Faktor pengetahuan yang dimiliki responden memegang peranan penting dalam penentu sikap yang utuh. Pengetahuan tersebut akan membentuk kepercayaan yang sifatnya akan memberikan dasar pembentukan sikap, maka harus memberikan kesan yangkuat.

Halini sesuai dengan penelitian yang dilakukan Kurnia (2014), mengemukakan bahwa pendidikan kesehatan HIV/AIDS dapat memberikan 
pengaruh yang signifikan pada pengetahuan tentang perilaku seksual dalam mencegah penyakit, mencegah penyalahgunaan obat serta menunda untuk melakukan hubungan seksual. Pendidikan kesehatan yang efektif menjadi tanggung jawab bagi individu untuk mencapai kesehatannya. Program pendidikan kesehatan yang diperlukan individu dapat memberikan informasi yang diperlukan dalam mengambil keputusan tentang kesehatan reproduksinya. Hal ini sesuai dengan hasil penelitian yang dilakukan oleh Arya (2015), mengemukakan bahwa pendidikan kesehatan mempunyai pengaruh yang positif pada kesadaran tentang HIVIAIDS dan peningkatan pengetahuan cara penularan dan sikap pencegahan HIVIAIDS. Artinya semakin baik pendidikan kesehatan yang diberikan maka semakin baik pula pengetahuanseseorangterhadap pencegahan HIVIAIDS.Peran tenaga kesehatan dalam memberikan pendidikan kesehatan sangat penting untuk meningkatkan pengetahuan, sikap dan perilaku seseorang. Pendidikan kesehatan tentang kesehatan reproduksi sangat penting diberikan oleh remaja.

Hal ini sesuai yang dikemukakan oleh Marmi (2014) bahwa masa remaja yang merupakan masa transisi dari masa anak - anak ke dewasa membuat rasa ingin tahu mereka tinggi. Pengetahuan yang kurang akurat tentang kesehatan reproduksi remaja terutama tentang seksual termasuk HIVIAIDS yang membuat masalah pada remaja dan akan berpengaruh terhadap sikap remaja. Jika remaja dapatmemberikansikap positif maka dapat meminimalisir terjadinya HIVIAIDS pada remaja. Pengetahuan merupakan faktor penentu yang penting untuk mengubah perilaku kesehatan (Karmin, 2012). Ada hubungan yang signifikan antara penggunaan media pembelajaran pada pendidikan tentang HIVIAIDS dan dapat meningkatkan pengetahuan remaja tentang penyakit HIVIAIDS (Adekola, 2014). Okoli (2016), menyatakan bahwa pendidikan akan mencapai tujuan lebih baik bila didukung atau menggunakan media pembelajaran. Sharma (2015), mengemukakan bahwa program pendidikan tentang HIVIAIDS bisa meningkatkan pengetahuan masyarakat tentang HIVIAIDS.

Penelitian yang dilakukan oleh Medley, Kennedey dan Sweat (2014) menyatakan bahwa efektivitas program pendidikan kesehatan dalam meningkatkan pengetahuan remaja Nigeria tentang HIVIAIDS memberikan pengaruh yang positif karena hasil uji statistik menunjukkan $p$ value0,000. Dampak perubahan sikap setelah diberikan pendidikan kesehatan karena dapat meningkatkan pengetahuan seseorang sehingga orang tersebut dapat memahami tentang sikap pencegahanHIVIAIDS.
Penelitian ini dari hasil kuesioner pretestdan posttestpeneliti menemukan adanya pengaruh pendidikan kesehatan terhadap pengetahuan remaja tentang HIVIAIDS pada remaja Akademi Keperawatan Pelamonia Kesdam VII/Wirabuana Makassar. Dari hasil uji statistik menggunakan uji WilcoxonSignRankTest nilai $p=0,000$. Nilai selisih rata-rata antara sebelum dan sesudah mengikuti pendidikan kesehatan cukup banyak yaitu hanya 5,53 begitu juga dengan nilai minimal dan maksimal sebelum dan sesudah dilakukan pendidikan kesehatan. Hal ini dikarenakan ada beberapa faktor yang mempengaruhi pengetahuan antara lain pendidikan, media massa/informasi, sosial budaya dan ekonomi, Lingkungan, Pengalaman, dan usia (Notoatmodjo, 2012).

\section{KESIMPULAN}

Berdasarkan hasil penelitian yang dilakukan di Akademi Keperawatan Pelamonia Kesdam VII/Wirabuana Makassar, diperoleh data yakni jumlah responden 92 orang, rata-rata jenis kelamin mayoritas perempuan dengan jumlah responden 75 orang, usia mayoritas 18 tahun sebanyak 48 orang. Hasil peneltian yang telah dilakukan yaitu terdapat pengaruh yang bermakna pendidikan kesehatan terhadap peningkatan pengetahuan remaja tentang HIVIAIDS.

\section{SARAN}

Berkaitan dengan semakin banyaknya remaja yang terjerumus kedalam pergaulan bebas hingga akhirnya terpapar dengan HIVIAIDS, maka diharapkan semua kalangan, khususnya bidang kesehatan dan sosial lebih gencar dan menyeluruh dalam memberikan pendidikan kesehatan dikalangan remaja.

Diharapkan kepada peneliti selanjunya untuk melakukan penelitian variabel-variabel baru yang berkaitan dengan reproduksi atau penyakit menular seksual dikalangan remaja di era milenial saat ini.

\section{UCAPAN TERIMA KASIH}

Penulis mengucapkan terimakasih kepada responden yang sudah bersedia meluangkan waktunya dalam penelitian ini, terimaksih pula kepada direktur Akper Pelamonia Kesdam VII/Wirabuana Makassar yang telah memberikan izin kepada penulis untuk melaksanakan penelitian ini. Penulis juga mengucapkan banyak terimaksih kepada temanteman yang sudah membantu dalam penelitian ini, sebagai moment untuk sharing dan beberapa masukan 


\section{DAFTAR PUSTAKA}

AdekolaG. 2014. The ImpactofInstructional Media ontheEducationofYouthson HIVIAIDS in Nigeria Urban Communities. International JournalofScientificResearch in Education, 3 (1),p. 64-72.

Hidayat, A. A. 2011. Metode Penelitian Kebidanan Dan TeknikAnalisis Data. Jakarta: Salemba Medika.

Irawan, S. 2017. Sulsel Darurat HIV/AIDS, Dinkes: Jangan Dijauhi, Tidak Menular, https://makassar.tribunnews.com/2018/11/16/sulsel-darurat-hivaids-dinkes-jangan-dijauhi-tidak-menular.

Karmin.2012. Students' SexualBehaviour in theContextof HIV/AidsEducation in PublicSecondarySchools: A CaseforKangudoDivision, Kenya, International JournalofHumanitiesandSocialScience,2 (23) December.

Kartini. 2010. Pengaruh Pelatihan HIVIAIDS terhadap pengetahuan dan sikap siswa tentang HIVIAIDS di SMU N 4 Wira Bangsa dan MAN Meulaboh I Kota Meulaboh Tahun 2010. Universitas Sumatera Utara

Kemenkes RI. 2018. Hasil utama riskesdas 2018. Jakarta: Kemenkes RI.

KPAN. 2010. Strategi Nasional Penanggulangan HIVIAIDS 2007-2010, Jakarta

Kurnia. 2014. Promosi Kesehatan Dalam Lingkup Kesehatan Reproduksi. Yogyakarta: Pustaka Cendekia

Marni.2014. Pengetahuan, Sikap Dan Perilaku Manusia.Yogyakarta: Nuha Medika

Medley A, at. all. (2014). Effectiveness of Peer Education Interventions for HIV Prevention in Developing Countries: A Systematic Review and Meta- Analysis, AIDS Education and Prevention, Guilford Press, 21(3),181-206.

Mustikasari, E. N. Faktor Pencegahan HIVIAIDS Akibat Perilaku Berisiko Tertular pada Siswa SLTP.Fakultas IImu Keperawatan Universitas Indonesia. http://journal.ui.ac.id/index.php/health/article/viewFile/360/356 diakses pada tanggal 12 Februari 2016 pukul 15.58 WIB.

Notodmodjo. 2012. Metodologi Penelitian Kesehatan. Jakarta: Rineka Cipta.

Okoli NJ. 2016. HIV/AIDS andYouths: TeachingMethods/Techniques, AwarenessCampaignandCommunity Service in Universityof Port HarcourtandEnvirons. A Paper PresentedattheWorkshoponthelntegrationof HIVIAIDS

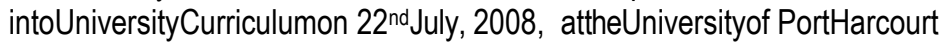

Sharma M. 2015. ImpactofEducationallnterventiononKnowledgeRegardingHIV/AIDS amongAdults. J Nepal HealthResCounc, 6(2).

Triwibowo, C dan Pusphandani, M E., 2015. Pengantar Dasar IImu Kesehatan Masyarakat Untuk Mahasiswa Kesehatan Masyarakat, Keperawatan dan Kebidanan. NuhaMedika,Yogyakarta. 